\title{
酸素の基本的な性質と安全性
}

日本酸素株式会社 橋 非一雄

\section{Fundamental Properties for Oxygen Application and its Handling Safety}

\author{
Kazuo Hashir
}

NIPPON SANSO K.K.

This article relates to some technical aspects of oxygen application and handling safety based on the fundamental chemical and phisical properties, phsiolosical effect, analytical procedures, production processes, and shipment to a customer.

Keywords: Oxygen, Safety, Pulping, Delignification

\section{はじめに}

酸素ガスの生産量は昭和 49 年約 90 億 $\mathrm{Nm}^{3}$ を記録 したが，オイルショック，ドルショックを経て低成長 安定型時代に入った昭和 50 年代から今日に至るまで 70〜80 億 $\mathrm{Nm}^{3}$ で推移している。酸素がこのように大 量に消費されているのは酸素ガスの基本的な性質であ る“酸化性”及び “支然性”をいろいろな工業的用途 に活用しているからである。基本的な利用の特徴をあ げると次のようになる。

1）酸化性の利用

（1）酸化反応により化成品の合成 一例，酸化エチレンやアルデヒドの製造

（2）酸化反応により不純物の分解・除去 一例，パルプ製造工程のリグニンの酸化分解 製鋼工程など炭素不純物の酸化分解

(3) 燃焼火炎の高温度の利用

一例，鋼材の溶接・切断

生石灰キルンヘの酸素富化, アルカリ回収ボ イラーの酸素富化

2）生体の呼吸用又は微生物・酵素の生物酸化性の 利用

一例，魚類養殖，発酵による食品製造，活性 污泥排水処理

酸素の詳しい工業的用途は表 11 に示した。
ところで，酸素利用の計两と実施，ならびにその設 備施工の面で忘れてはならない酸素なるがゆえの注意 事項は「酸素ガスは無味・無臭・無色でそれ自身は然 焼しないが，物を然焼させるのには不可欠であって(1) その発火エネルギーは空気中より小さく(2)火炎温度が 高くなり(3)可然性物質との然焼範囲も抎大し(4)空気中 では燃燒しない物質も酸素中では激しく燃煔する」こ とである。そこで禁油，ガス漏泚方止措置をはじめ, 設計・材料・機器の遙定の面からも「酸素なるがゆ兄 の性質」を配虑したエンジニヤリングが必要となる。 一例をあげると酸素配管などの施工に括いては，当然 ながら「これら配管や機器の中には油脂・鉄錆・鉄 粉・溶接くずなど可然物を介在させないこと」が安全 の基本になる。

本稿は酸素の基本的な性質と安全性に主腿を监いて 酸素の基礎，製造と供給，取扱い，用途を解説し紙パ ルプ製造工程での効率的で安全な酸素利用に資するよ らまとめてみた。

\section{1. 酸素の基礎}

\section{1 酸素の発見}

18 世紀の中頃まで，すべての空気成分気体は大気 と混同されていた。当時の化学者は個々の物質として 幾つかの気体を知ってはいたが，これはすべて「空気」 と総称され，それぞれの㕮体の反応は大父中に入って 
くるさまざまな呮合物のためであると考えていた。こ の時代に J. Black は化学反応封の重量变化加定量 的研究の先べんをつけた。更に J. Priestry，H. Cavendish はヘイルズの集気びんを改良して二酸化炭素, 二酸化硫黄，㙁化水素など水によく溶ける気体の研究 を進めることができるようになった。

然焼の本性が一休何であるかは Priestley（イギリ ス）の父休の矿笲及び K. W. Scheele(スウェーデン) の空気中の二大成分の発見によって正しく認識できる ようになった。Priestley によって酸素の本格的分離 が行われた。1774年水銀を空父中で熱してでさる赤

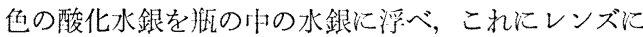
よって太陽熱を集中するとガス体が発生することを認 め，これが燃毞を著るしく支持する一種の空気である ことを確めた。最初は支燃性だけを実験したので支呼 吸性には考党が及ばなかったが，翌年この気体の中で ネズミが長く生きることから支呼吸性に気付き，純粋 な空気として涚フロギストン空気と命名した。この空 気こそ酸素だったのであるが，彼の発見の内容を正し 〈理解し発展させたのは後述するフランスの A.L. Lavoisier である。

一方，スウェーデンの K. W. Scheele は硝石，酸 化水銀などを熱するとき父体が発生し，その中で木炭 やロウが大気中よりも激しく燃えることを認めて Fire Air と命名し，空父の一成分であることを推定 した。この央験は 1773 年以前に行われていたが，そ の論文を発行したのが 1777 年と打くれたため酸素発 見の優先権は Priestley に帰せられたのである。

1774 年 Priestley は Lavoisier（フランス）に彼が 最近発見した正体のよく分らない新しい空気について 語った。これが当㭙燃㹸と空父の関係につき研究して いた Lavoisier に重大なヒントを与兄た。すなわち, この気体が呼吸・燃绫に役立つ空気の成分であって， 燃烓は物質とこの父体の結合であることに考学つき定 量的にこれを証明した。1777 年 Lavoisier が書いた 論文で，その父休に酸絜（オキシジェン）と名づけて いる。望源はギリシャ活の Oxy 酸味のある+Genes 生ずるである。

\section{2 酸素の物理的化学的性質}

酸素は大部分の他元素と化合（抒もに酸化）しその 一形隹として燃炧あるいは爆発がある。特殊な反応と して炭化水素や炭水化物と反応して，アルコールやア ルデヒドなどを生ずる緩慢な酸化がある。酸素の気体 は無色であるが加圧冷却すれば淡青色の液体，青色の 固体となる。これは可視部の赤色光 $6300 \AA$ を吸収す るためで目で見た仰は青隽である。
表 1 温度別飽和溶存酸素量 $(\mathrm{ppm})$

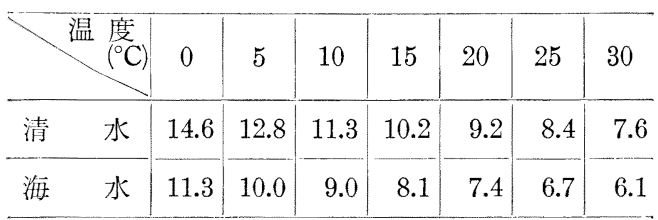

酸素ガスはある程度水汇溶解する1。溶解量は表 1 に示す通りである。 $20^{\circ} \mathrm{C}, 760 \mathrm{mmHg}$ の気体酸素と 㑕触して飽和している水 $1 l$ 亿酸素 $0.0434 \mathrm{gr}\left(0^{\circ} \mathrm{C}\right.$ $760 \mathrm{mmHg}$ 亿換算して $0.0310 l$ ）が溶けている。 $20^{\circ} \mathrm{C}$, $760 \mathrm{mmHg}$ の大気 $\left(\mathrm{O}_{2} 20.9 \%\right.$ を含み，水蒸気が飽和 しているとき）と接触している水 $1 l$ 中の酸素の飽和 量（溶存酸素量 $\mathrm{O}_{2} \mathrm{mg} /$ 水 $1 l$ ) は $8.84 \mathrm{mg}(8.84 \mathrm{ppm})$ である。また水と接触する界面又は空間の気体圧力と 飽和溶存酸素量との関係は図 1 亿示すように，同じ酸

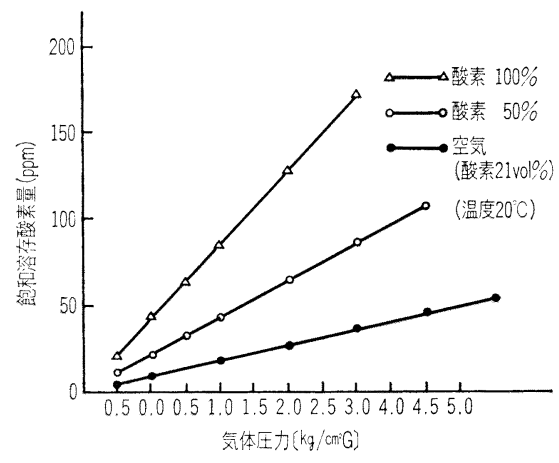

図 1 気体圧力と飽和溶存酸素量

素濃度であれば圧力が高い添ど溶存量は大さく，同一 圧力であれば酸素濃度が高い注ど溶存酸素量は大さい。 したがって空気中の約 $21 \%$ の酸素を使うよりも純酸 素を使用したほうが湿式酸化反応，生物酸化反応には 好ましいとの考兄が生れる。

表 2 亿酸素の物理的化学的性質を一括して示す2)。

表 2 酸素の物理的化学的性質

\begin{tabular}{|c|c|c|}
\hline 項 & 目 & その内容・データ \\
\hline 化 学 & 式 & $\mathrm{O}_{2}$ (分子量 31.999 ) \\
\hline 外 & 観 & 気体は無色。液体法淡青色 \\
\hline 密 & 度 & 気体 $1.429 \mathrm{~kg} / \mathrm{m}^{3}\left(0^{\circ} \mathrm{C} \quad 1 \mathrm{~atm}\right)$ \\
\hline 比 & 重 & 1.1049 (空気 1 ) \\
\hline 比 容 & 積 & $0.6997 \mathrm{~m}^{3} / \mathrm{kg}\left(0^{\circ} \mathrm{C} 1 \mathrm{~atm}\right)$ \\
\hline 沸 & 点 & $-183^{\circ} \mathrm{C}$ \\
\hline 融 & 点 & $\begin{array}{l}-218.8^{\circ} \mathrm{C}(\text { (三重点 圧力 } 1.2 \mathrm{mmHg} \\
3.33 \mathrm{kcal} / \mathrm{kg})\end{array}$ \\
\hline
\end{tabular}




\begin{tabular}{|c|c|}
\hline 臨 界 温 度 & $-118.4^{\circ} \mathrm{C}$ \\
\hline 㯺 界 压力 & $50.1 \mathrm{~atm}$ \\
\hline 臨界密度 & $0.427 \mathrm{~kg} / \mathrm{m}^{3}$ \\
\hline 比熱 & $\begin{array}{l}\mathrm{C}_{\mathrm{p}} 0.2187 \mathrm{cal} / \mathrm{gr}\left(20^{\circ} \mathrm{C} 1 \mathrm{~atm}\right) \\
\mathrm{C}_{\mathrm{v}} 0.1566 \mathrm{cal} / \mathrm{gr}\left(20^{\circ} \mathrm{C} 1 \mathrm{~atm}\right) \\
\mathrm{C}_{\mathrm{p}} / \mathrm{C}_{\mathrm{v}}=1.4\end{array}$ \\
\hline 熱 伝䁉 度 & $0.0197 \mathrm{kcal} / \mathrm{m} \cdot \mathrm{hr} \cdot{ }^{\circ} \mathrm{C}\left(0^{\circ} \mathrm{C} 1 \mathrm{~atm}\right)$ \\
\hline 粘 性 係 数 & $1.95 \times 10^{-6} \mathrm{~kg} \cdot \mathrm{sec} / \mathrm{m}^{2}\left(0^{\circ} \mathrm{C} 1 \mathrm{~atm}\right)$ \\
\hline 水に対する溶 & $49.1 \mathrm{cc} / \mathrm{H}_{2} \mathrm{O} / l\left(0^{\circ} \mathrm{C} 1 \mathrm{~atm}\right)$ \\
\hline & $31.0 \mathrm{cc} / \mathrm{H}_{2} \mathrm{O} / l\left(20^{\circ} \mathrm{C} 1 \mathrm{~atm}\right)$ \\
\hline ガス密度 & $4,740 \mathrm{~kg} / \mathrm{m}^{3}\left(-183^{\circ} \mathrm{C}\right)$ \\
\hline 液 密 度 & $1.141 \mathrm{~kg} / \mathrm{l}\left(-183^{\circ} \mathrm{C}\right)$ \\
\hline $\begin{array}{l}\text { 液体・気体の } \\
\text { 体積膨張比 }\end{array}$ & $875 \AA$ \\
\hline 酸素分子の大 & 分子の長さ (長軸) $4.18 \AA$ \\
\hline & 分子の幅 (短軸) $3.18 \AA$ \\
\hline $\begin{array}{l}\text { 酸素平衝原子 } \\
\text { 間離 }\end{array}$ & 1.2074 \\
\hline $\begin{array}{l}\text { 酸素分子の解 } \\
\text { 離エネルギー }\end{array}$ & $5.1148 \mathrm{eV}, 117.96 \pm 0.04 \mathrm{kcal} / \mathrm{mole}$ \\
\hline 固 体 酸 素 & $\alpha$ 相 $\underset{\text { 系 }}{23.89^{\circ} \mathrm{K} \text { 以下で存在，単斜丽 }}$ \\
\hline & $\beta$ 相 $\begin{array}{c}23.89 \sim 43.78^{\circ} \mathrm{K} \text { で存在, 六方 } \\
\text { 系 }\end{array}$ \\
\hline & 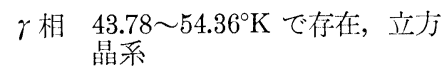 \\
\hline $\begin{array}{l}\text { 非放射性同位 } \\
\text { 元素 }\end{array}$ & $\begin{array}{l}\mathrm{O}^{16}\left(\text { 質量数 } 16 \text { ) } 99.759 \%, \mathrm{O}^{17} \text { (同 } 17\right) \\
\left.0.037 \%, \mathrm{O}^{18} \text { (同 } 18\right) 0.204 \%\end{array}$ \\
\hline
\end{tabular}

\section{3 酸素分子の構造と酸素なるがゆえの性質}

酸素の分子構造と酸素の活力との間にどのような関 係があるかを原子構造から考皇てみたい。

原子の構造と周期律は図 2 のと和りで, 酸素の位㹕 付けが理解される。窒素原子, 酸素原子は $\mathrm{P}$ 軌道に電 子を有するから， $\mathrm{S}$ 規道にしか電子を有しない水素に 比べそれだけ原子は複雑となる。更に，それぞれの 2 個の原子から構成される分子の分子軌道と外殼電子を
考觉ると，空素分子は $\mathrm{P}$ 軌道比 3 個の電子があるから， 空素分子では 6 倜の電子を有することになる。3 個の シグマ，パイ軌道をP Pauli の原理にしたがって軌道を 渾たし安定な窒素分子となる。このような構造から窒 素分子すなわち窒素ガスは不活性（安定）であり反応 性に元しい。

活性な酸素分子とその原因「ラジカル」を考觉る。

酸素分子も安定な空素分了と同じ軌道をもつぶ，酸 素原子の電子数は 8 であるから空素原子の電子数 7 よ り 1 個多く，したがって凌素原子はP 軌道に 4 個の電 子を有するから，酸装分子は 8 個の電子を有すること になる。そこでエネルギーの宫いパイ反結合軌道にま で電子が入るが，エネルギーが等しい2 個の軌道に 1 つずつ分れて入っている。なぜ 1 つの軌道に 2 婀の電 子が入って安定にならないかについて補足すると，軌 道のエネルギーが等しいか, 坡が小さい場合には電子 は別々の軌道に分れて入ることができる。このように 1 つの軌道に 1 個の電子が入っている場会, これを不 刘電子と呼ぶ。 1 つの軌道に 2 佔の電子が入った場合 を電子対という。この不対電子は一般に反応性が強く 他の原子や分子の電子と䌃合しやすい。これを自由に 結合でさる原子価があると考光, 遊離の原子価（フリ 一バレンス)，あるいは遊離基（フリーラジカル）略 してラジカルと言う。これが䣲素分子, すなわち酸素 ガスの活性の原因である。

酸素分子など 2 原子間の切断にどの位のエネルギー が必要であるのか，すなわち解離エネルギーを表 $3{ }^{32}$ に示す。この表から陵絜は自然界特に大気中に存在し ている極くありふれた父体の中では比較的小さい值で あることが分る。

\section{4 酸素の生体に対する作用}

大気中の酸素濃度が現在の $21 \%$ 程度になったのは

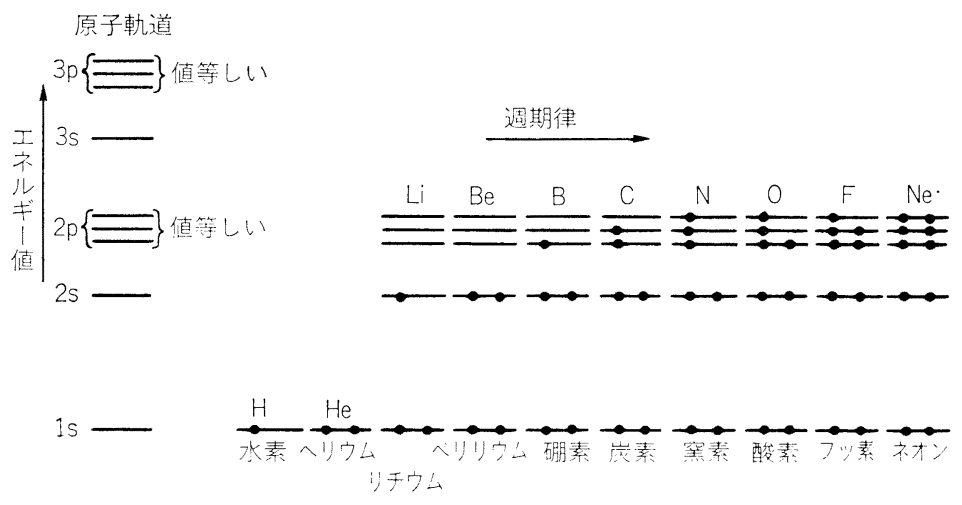

図 2 原子の構造と周期律 
表 3 分了の解晟エネルギー $(\mathrm{E}: \mathrm{eV})$

\begin{tabular}{|c|c|c|}
\hline 分 & 解谁一る位罪 & $\mathrm{E}$ \\
\hline $\mathrm{H}_{2}$ & $(\mathrm{H}-\mathrm{H})$ & 4.4773 \\
\hline $\mathrm{N}_{2}$ & $(\mathrm{~N}-\mathrm{N})$ & 9.760 \\
\hline $\mathrm{O}_{2}$ & $(\mathrm{O}-\mathrm{O})$ & $5.114_{8}$ \\
\hline $\mathrm{F}_{2}$ & $(\mathrm{~F}-\mathrm{F})$ & 1.59 \\
\hline $\mathrm{Cl}_{2}$ & $(\mathrm{Cl}-\mathrm{Cl})$ & 2.476 \\
\hline $\mathrm{Br}_{2}$ & $(\mathrm{Br}-\mathrm{Br})$ & 1.970 \\
\hline $\mathrm{I}_{2}$ & $(1-1)$ & 1.5439 \\
\hline $\mathrm{CO}$ & $(\mathrm{C}-\mathrm{O})$ & 11.09 \\
\hline NO & $(\mathrm{N}-\mathrm{O})$ & 6.50 \\
\hline $\mathrm{H}_{2} \mathrm{O}$ & $(\mathrm{H}-\mathrm{OH})$ & $5.113_{6}$ \\
\hline $\mathrm{H}_{2} \mathrm{~S}$ & $(\mathrm{H}-\mathrm{SH})$ & 3.26 \\
\hline $\mathrm{CO}_{2}$ & $(\mathrm{O}-\mathrm{CO})$ & 5.453 \\
\hline \multirow[t]{2}{*}{$\mathrm{N}_{2} \mathrm{O}$} & $\left(\mathrm{N}_{2}-\mathrm{O}\right)$ & 1.677 \\
\hline & $(\mathrm{N}-\mathrm{NO})$ & 4.930 \\
\hline $\mathrm{SO}_{2}$ & $(\mathrm{OS}-\mathrm{O})$ & $5.61_{3}$ \\
\hline $\mathrm{O}_{3}$ & $\left(\mathrm{O}_{2}-\mathrm{O}\right)$ & $1.0_{4}$ \\
\hline $\mathrm{NH}_{3}$ & $\left(\mathrm{H}-\mathrm{NH}_{2}\right)$ & $4.3_{8}$ \\
\hline $\mathrm{CH}_{4}$ & $\left(\mathrm{CH}_{3}-\mathrm{H}\right)$ & $4.40_{6}$ \\
\hline $\mathrm{C}_{2} \mathrm{H}_{2}$ & $(\mathrm{HC}-\mathrm{CH})$ & $9.88_{6}$ \\
\hline
\end{tabular}

約 2.5 億年前と考学られている。それ以前はかなり低 濃度で，地球生成の听の大父は酸素分圧が $10^{-8}$ 気压 程度と推定されている。今から約 6 億年前, 海中の緑 色植物によってかなりの量の酸素が生成され大気中の 酸素量は現在の $1 / 100$ ほどになった。そうなると太陽 からの紫外線は弱末り, 生物は爆発的に多様多彩とな って生物による酸索生産最が急激に増えた。今から 4 億年前には酸菜分川:は現在量の $1 / 10$ までになって，

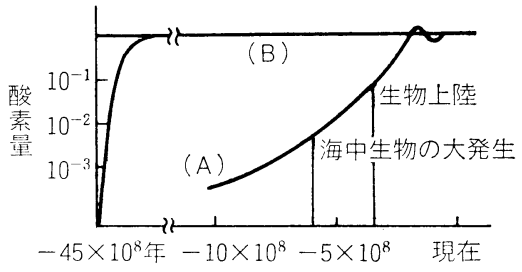

(B) $\mathrm{H}_{2} \mathrm{O} \rightarrow \mathrm{H}_{2}+1 / 2 \mathrm{O}_{2} \cdots$ (清水)

(A) 炭酸同化作用…(バークナー、マーシャル)

図 3 大父中の酸素分圧の変逻

陸上植物の発生が光合成活動を飛躍的に活発化し，地 球大気のレベルに一挙に達した。（一説には光合成と ともに紫外線による水蒸気の分解で酸素分圧が増加し たとの学説もある) 図 3 参照

空気中の酸素濃度 $21 \%$ (大気圧 $760 \mathrm{mmHg}$ のも で $159.2 \mathrm{mmHg}$ の酸素分圧）という值は我々の生体 に最も適している。人間の生体の諸機能がこの酸素濃 度で最も効率よく働いて招り，これより低濃度でも高 濃度でもその機能は不調となる。人は空気を呼吸し， 折液 $100 \mathrm{ml}$ につき約 $20 \mathrm{ml}\left(0^{\circ} \mathrm{C} 760 \mathrm{mmHg}\right)$ の $\mathrm{O}_{2}$ をとり达んで各組織に送り，栄養物質を酸化すること により生ずるエネルギーを利用して活動を続けている。 大人 1 人が 1 日に $3,000 \mathrm{kcal}$ のエネルギーをらみ出 すためには平均 $612 l$ ( 1 気圧, 室温) の $\mathrm{O}_{2}$ を必要 とする。 $\mathrm{CO}_{2}$ 吐出量は約 $511 \mathrm{l} /$ 日で消費した酸素量と 吐出した炭酸ガス量の容積比は大体 $\mathrm{CO}_{2} / \mathrm{O}_{2}=0.82 \sim$ 0.85 である。

人の呼吸で，空気中酸素濃度の正常状態の下限は

表 4 空父中の酸素濃度と肺胞内及び血液中の酸素分压

\begin{tabular}{|c|c|c|c|c|c|c|}
\hline \multirow{3}{*}{$\begin{array}{c}\text { 空父中の } \\
\text { 陵素浀度 } \\
\% \\
\%\end{array}$} & \multicolumn{2}{|c|}{ 酸 } & \multicolumn{3}{|c|}{ 压 $\mathrm{mmHg}$} & \multirow{3}{*}{$\begin{array}{l}\text { 安全性, 並 } \\
\text { 飞危険度 }\end{array}$} \\
\hline & \multirow{2}{*}{$\begin{array}{l}\text { 空䒝中 } \\
\text { 酸素分王 }\end{array}$} & \multirow{2}{*}{$\begin{array}{l}\text { 肺胞内吸気 } \\
\text { の酸素分压 }\end{array}$} & \multicolumn{3}{|c|}{ 血液 中 の 酸素 } & \\
\hline & & & 酸 素 分 王 & 飽 牙 & 和 度 & \\
\hline 23 & $\underset{174.8}{\mathrm{mmHg}}$ & $\begin{array}{r}\mathrm{mmHg} \\
121.5\end{array}$ & & & & 安 全 \\
\hline 21 & 159.6 & 110.9 & $\begin{array}{l}\mathrm{mmHg} \\
103.0\end{array}$ & & $97 \%$ & 安 \\
\hline 19 & 144.4 & 100.4 & 91.0 & & 96 & 安 \\
\hline 17 & 129.2 & 89.8 & 78.0 & & 93 & $\begin{array}{l}\text { 稍異状を生ずる } \\
\text { 判にぶる }\end{array}$ \\
\hline 15 & 114.0 & 79.2 & 64.0 & & 88 & $\begin{array}{l}\text { 安全の最低限度 } \\
\text { 嘔吐, 呼吸困難 }\end{array}$ \\
\hline 13 & 98.8 & 68.7 & 53.0 & & 85 & $\begin{array}{l}\text { 生活可能の最低 } \\
\text { 線 }\end{array}$ \\
\hline 11 & 83.6 & 58.1 & 42.0 & & 78 & 意識喪 失 \\
\hline 5 & 38.0 & 26.4 & 18.0 & & 33 & $\begin{array}{l}\text { 聋睡, } 6 \text { 分で呼 } \\
\text { 停止 }\end{array}$ \\
\hline
\end{tabular}


表 5 測定用酸素分析計

\begin{tabular}{|c|c|c|c|c|c|c|}
\hline 分 析計(法) & 測 定 原 理 & 測定範用 & 測定精度 & $\begin{array}{l}\text { 試料ガス } \\
\text { 流 量 }\end{array}$ & $\begin{array}{l}\text { 分析 } \\
\text { 所要時間 }\end{array}$ & 摘 \\
\hline $\begin{array}{l}\text { 黄燐発光式微量 } \\
\text { 酸素分析計 }\end{array}$ & $\begin{array}{l}\text { 黄燐之酸素の反 } \\
\text { 応による発光量 } \\
\text { 測定 }\end{array}$ & $\begin{array}{l}0 \sim 10 \mathrm{ppm} \\
0 \sim 20 \\
0 \sim 50\end{array}$ & $\pm 2 \%$ & $1.8 \mathrm{l} / \mathrm{min}$ & $5 \mathrm{~min}$ & $\begin{array}{l}\text { 記録訣の接続可 } \\
\text { 測定用管源队蔵 } \\
\text { ポータブル型 }\end{array}$ \\
\hline $\begin{array}{l}\text { 隔膜ガルバ二セ } \\
\text { ル式酸素計 }\end{array}$ & $\begin{array}{l}\text { 薄膜ガルバ=電 } \\
\text { 池式 }\end{array}$ & $0 \sim 50 \%$ & $\pm 5 \%$ & - & - & \\
\hline $\begin{array}{l}\text { ガルバニックセ } \\
\text { ル型微量酸素分 } \\
\text { 析計 }\end{array}$ & $\begin{array}{l}\text { ガルバニックセ } \\
\text { ルの起電力を測 } \\
\text { 定 }\end{array}$ & $\begin{array}{l}0 \sim 10 \mathrm{ppm} \\
0 \sim 20 \\
0 \sim 100\end{array}$ & \pm 1 & 2 & $5 \mathrm{~min}$ & $\begin{array}{l}\text { 䛉録計の接続可 } \\
\text { ボータブル型も有 }\end{array}$ \\
\hline $\begin{array}{l}\text { セラミック式酸 } \\
\text { 素分析計 }\end{array}$ & $\begin{array}{l}\text { 酸素濃淡電池の } \\
\text { 起電力を測定 }\end{array}$ & $\begin{array}{c}0.1 \sim 20 \\
/ 1 \sim 20 \% \\
1 \sim 100 \mathrm{ppm} \\
98 \sim 100 \% \\
\end{array}$ & $\begin{array}{l} \pm 2.0 \% \\
\pm 2.5 \% \\
-\end{array}$ & $\begin{array}{l}0.5 \\
0.5 \\
0.1\end{array}$ & $5 \mathrm{~min}$ & 同 \\
\hline $\begin{array}{l}\text { ガスクロマトグ } \\
\text { ラフ }\end{array}$ & $\begin{array}{l}\text { 予め吸着剂によ } \\
\text { り各成分に分離 } \\
\text { したガスの熱伝 } \\
\text { 導度測定 }\end{array}$ & $20 \mathrm{ppm}$ 以上 & \pm 2 & 1 回に $5 \mathrm{cc}$ & $10 \mathrm{~min}$ & - \\
\hline ウインクラー法 & $\begin{array}{l}\text { 酸素による沃素 } \\
\text { イオの酸化度 } \\
\text { 合を測定 }\end{array}$ & $0 \sim 100 \mathrm{ppm}$ & \pm 2 & 1 回に $1 l$ & $3 \mathrm{hr}$ & 化学分析 \\
\hline $\begin{array}{l}\text { 酸素ガス漏洩警 } \\
\text { 報器 }\end{array}$ & $\begin{array}{l}\text { 特殊ガルバ二電 } \\
\text { 池方式 }\end{array}$ & $0 \sim 50 \%$ & $\pm 5 \%$ & - & 30 秒 $>$ & $\begin{array}{l}\text { 警報濃度 } \\
25 \% \pm 5 \% \mathrm{O}_{2} \\
\end{array}$ \\
\hline $\begin{array}{l}\text { ポータブル酸素 } \\
\text { 濃度計 }\end{array}$ & 同上 & $\begin{array}{l}0 \sim 25 \% \\
0 \sim 100 \%\end{array}$ & \pm 0.5 & & 5 秒 $>$ & $\begin{array}{l}\text { 同上涨度 } \\
18 \% \mathrm{O}_{2}\end{array}$ \\
\hline
\end{tabular}

表 6 正常な空気組成とその沸点

\begin{tabular}{|c|c|c|c|c|}
\hline 空気中の成分 & 化 学 式 & 分 子 量 & 乾燥空気中の成 & 沸 点 $\left({ }^{\circ} \mathrm{C}\right)$ \\
\hline 窒素 & $\mathrm{N}_{2}$ & 28.016 & 78.03 vol & -195.80 \\
\hline 酸素 & $\mathrm{O}_{2}$ & 32.000 & 20.95 & -182.97 \\
\hline アル ゴン & $\mathrm{Ar}$ & 39.944 & 0.932 & -185.86 \\
\hline 炭 酸 ガ ス & $\mathrm{CO}_{2}$ & 44.011 & 0.03 & - 78.45(昗華) \\
\hline ネオン & $\mathrm{Ne}$ & 20.183 & 18.21 & -245.9 \\
\hline へリウ ム & $\mathrm{He}$ & 4.003 & 5.24 & -268.93 \\
\hline クリプトン & $\mathrm{Kr}$ & 83.8 & 1.139 & -153.40 \\
\hline キセノン & $\mathrm{Xe}$ & 131.30 & 0.086 & -108.12 \\
\hline 水 素 & $\mathrm{H}_{2}$ & 2.016 & $0.13 \sim 2.0$ & -252.77 \\
\hline 西酸化窒菜 & $\mathrm{N}_{2} \mathrm{O}$ & 44.016 & 約 $\quad 0.5$ & -88.47 \\
\hline オ ゾ ン & $\mathrm{O}_{3}$ & 48.000 & $0 \sim 0.05 \quad$ & -111.9 \\
\hline 一酸化炭素 & $\mathrm{CO}$ & 28.011 & 35 以下 " & -191.52 \\
\hline アセチレン & $\mathrm{C}_{2} \mathrm{H}_{2}$ & 26.038 & $0.001 \sim 1$ & -84.03 \\
\hline タ & $\mathrm{CH}_{4}$ & 16.043 & 約 & -161.49 \\
\hline エ タ & $\mathrm{C}_{2} \mathrm{H}_{6}$ & 30.07 & 0.1 & -88.63 \\
\hline
\end{tabular}

注：標記成分以外にェチレン・プロパンなどの炭化水素及び严硫酸ガス・硫化水素などの硫黄化合物がごく碳 量存在することもある。 
19\%といわれている。（表 4 参照）

地球上での光合成による院素生成量は年間約 $1.5 \times$ $10^{6} \mathrm{t}$ と推定されている。一少，地球上の酸素の量は ほとんど变っていないようである。1960年から10 年 間にわたってアメリカで主として海洋上（北緯 $50^{\circ}$ か ら南緯 $60^{\circ}$ にわたる）で測定された結果では大気中の 酸素浀度にまったく変化は涊められなかった。

\section{5 酸素の分析と検知}

酸素の分析は p.p.m. から％単位までいろいろのレ ベルで行われる。分析の目的は製品としての酸素ガス （通常 $99.6 \%$ 以上）の品質確認, 燃焼排ガス中の残存 $\mathrm{O}_{2}$ 濃度管理（通常 $5 \%$ 以下)，酸化反応など工業プロ セスに供給する酸素ガスの純度確認（通常 $99.6 \%$ 以 上), 不活性ガスシールあるいは還元性䨌囲気を保持

表 7 酸素製造装置の発達史

\begin{tabular}{|c|c|c|c|}
\hline 西 暦 & 元 晃 & 本 & 海外 \\
\hline 1857 & & & $\begin{array}{l}\text { W.ジーメンスによる向流熱交換原理 } \\
\text { 発見 }\end{array}$ \\
\hline 1862 & & & 旌ュール・トムソンによる発見 \\
\hline 1873 & & & $\begin{array}{l}\text { カール・フォン・リンデによるアンモ } \\
\text { ニア冷涷機開発 }\end{array}$ \\
\hline 1895 & & & $\begin{array}{l}\text { カール・フォン・リンデによる空気液 } \\
\text { 化実験 }\end{array}$ \\
\hline 1902 & & & $\begin{array}{l}\text { 同リンデによる精溜法の確立 } \\
\text { ジョルジュ・クロ精溜法開 } \\
\text { 発 }\end{array}$ \\
\hline 1910 & & & $\begin{array}{l}\text { リンデ社による複精溜酸素製造装置開 } \\
\text { 発 }\end{array}$ \\
\hline 1911 & 明治 44 & $\begin{array}{l}\text { 日本酸素, ヒルデプランド社製単精溜・酸素 }\left(10 \mathrm{M}^{3} / \mathrm{h}\right) \\
\text { 製造装を購入し稼動開始 }\end{array}$ & \\
\hline 1913 & 大正 2 & 日本空素肥料秝クロード社製窒素分離装置輸入 & \\
\hline 1925 & 同 14 & & $\begin{array}{l}\text { M. フレンケルによる蓄冷器採用の空 } \\
\text { 気液化分離法の考案 }\end{array}$ \\
\hline 1929 & 炤和 4 & $\begin{array}{l}\text { 日本酸素，ハイランド社製複精溜・酸素 }\left(50 \mathrm{M}^{3} / \mathrm{h}\right) \text { 製 } \\
\text { 造装唯を購入して操業 }\end{array}$ & \\
\hline 1932 & & & $\begin{array}{l}\text { リンデ社, } 1,600 \mathrm{M}^{3} / \mathrm{h} \text { 酸素製造装置 } \\
\text { 製作。衝動式膨張ターヒビ試用, } 1936 \\
\text { 年採用。(大型化始り) }\end{array}$ \\
\hline 1934 & 同 9 & 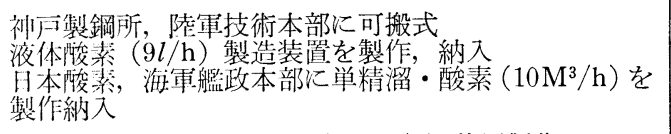 & \\
\hline 1935 & 同 10 & 日本酸素，複精溜・酸素 $\left(40 \mathrm{M}^{3} / \mathrm{h}\right)$ 装置製作 & \\
\hline 1937 & & & リンデ・フレンケル特許成立 \\
\hline 1939 & & & $\begin{array}{l}\text { ソビエット, P. L.キャピッアによる } \\
\text { 反動式膨張タービン開溌と空気液化の } \\
\text { 報告 }\end{array}$ \\
\hline 1940 & & & $\begin{array}{l}\text { 米国, 軍需目的の酸素製造装置の開発 } \\
\text { チーム (NDRC) が発足 }\end{array}$ \\
\hline 1947 & & & $\begin{array}{l}\text { 米国, Kellog 社, Elliott 社ともに酸 } \\
\text { 素大型装置の開発・試作 }\end{array}$ \\
\hline 1948 & & & 米国，酸素の量産化計画ラッシェ \\
\hline 1949 & 同 24 & $\begin{array}{l}\text { 理化学研究所・日本理化低压式酸素製造装置の試作 } \\
\text { (拜式膨張タービンの試作採用) }\end{array}$ & \\
\hline 1953 & 同 28 & $\begin{array}{l}\text { 日立製作所同上の機種酸素 }\left(300 \mathrm{M}^{3} / \mathrm{h}\right) \text { の製作を本格 } \\
\text { 的に取組, 開始 }\end{array}$ & \\
\hline 1954 & 同 29 & $\begin{array}{l}\text { 日本酸素, 液体酸素製造装置 }\left(500 \mathrm{M}^{3} / \mathrm{h}\right) \quad 1 \text { 号機国産 } \\
\text { 化自社问操業始める。（液酸時代の始り） }\end{array}$ & \\
\hline 1959 & 同 34 & $\begin{array}{l}\text { 神戸製鋼所（ }\left(10,000 \mathrm{M}^{3} / \mathrm{h}\right) \text { 酸素製造装置製作，（超大 } \\
\text { 型化の始り） }\end{array}$ & \\
\hline 1971 & 同 46 & 日本酸素，LNG 寒冷利用の酸素製造装置製作 & \\
\hline 1972 & 同 47 & 日本酸素 $\left(35,000 \mathrm{M}^{3} / \mathrm{h}\right)$ 装置製作 & \\
\hline
\end{tabular}


するための微量酸素濃度の測定管理（通常数 ppm か ら $1 \mathrm{ppm}$, 例: 半導体工業や金属工業保護ガス工程, LNG LPG タンクの窒素パージ)などのためである。 現在使用されている酸素濃度分析計を表 5 亿示す。

\section{2. 酸素の製造と供給}

\section{1 酸素製造の基本原理と製造法の展開}

工業的酸素製造法として広く採用されている空気液 化精溜分離法は空父（表 6 参照）を適切な寒冷発生手 段により液体空気とし，ついで酸素，アルゴン，空素 などその沸点差を利用して精溜分離することを基本原 理とする。また基本操作は压縮した原料空気の断熱膨 張による寒冷の発生, 原料空気と酸素, 窒素製品間の 熱交換に上る寒冷の回収である。これらの基本原理及 び操作によって 1930 年代に大規模製造装置が開発さ れた。我が国注括的る酸素の製造は生産能力每時 10 $\mathrm{Nm}^{3}$ の装置をドイツから輸入した 1911 年に始る。戦 後になり装置の開発と大型化が進み, 1972 年に 35,000 $\mathrm{Nm}^{3} / \mathrm{h}$ と世界的規模のプラントが稼動するまでにい たった。(表 7 参照)

米国は我が国と同様、空父深冷分離法による酸素製造 に関しては後進国であって, $10,000 \mathrm{Nm}^{3} / \mathrm{h}$ 級の大型装 置が稼動したのは1940年代の後半になってからである。

ところで, 酸素製造装置の発達をふりか兄ると 1895 年ドイッの C. V. リンデは, 寒冷発生の方法としてジ ユール及びトムソンの絞り効果原理（1862 年）を応用 し，寒冷回収法として，W.シーメンスによる向流法 熱交換原理（1852 年）を採用した空気液化法を開発し たが，これでは単に空気を液化したにすぎず酸素を得 るには至らなかった。1905年液化空気の精溜操作を 試及単精溜法に基づく酸素製造法を確立した。しかし 単式精溜法は酸素純度が低いため 1910 年に複式精溜 法が開発され高純度の酸素の製造が可能となった。

さて，本法による“空気加酸素を工業的䐆取す る陚み”を実践した開拓者はドイッのリンデとともに フランスのクロード及びドイッのハイランドが著名で ある。彼らは空気の液化に必要な寒冷発生手段として 澎張機を導入することを独立に考案（クロード：1902 年，ハイランド：1908 年）した。この方法は断熱膨張 により気体にも積極的に仕事をさせるため, リンデの 方法に比較して空気液化の效率を著るしく向上させた。 このような過程を経て, 空気から酸素を得る空気分離 法の基礎は固められた。しかし今日の大量かつ経済的 に酸素を製造することができるようになったのはドイ ッの M. フレンケルによる蓄冷器（熱交換器の一種） の開発とソ連の P. L. カピッアによる膨張タービンの
開発（1939 年）による。

M. フレンケルが発明した湆冷器は蕃冷の原理で作 動する切換式機構を有し，単位堔䅡あたりの伝熱面程 が大きくて熱交換効率が良く，正力損失が極めて少い という長所を具備しているので，大容量の原料空気と 低温製品ガスとの熱交換が可能となった。またこの蓄

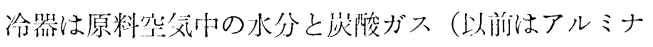

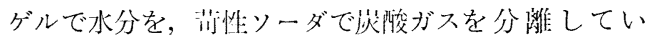
た）を冷却過程で固化分離し，パージガス（製品寉惄 を主に使用）で完全に除去することができる。前記 2 成分の除去系統が省略できることで大型化の推進と操 作性の向上が奏現した。

P. L. カピッアは反動式膨张タービンの武作をすす め空氛の液化に成功した。從来, 笭泠発生手段として 採用されていた衝動式澎張タービンに比べ，この方式 では压縮空気の膨張をノズル及びロータ一翼内と 2 段 に分けて行らことによって，そこでの摩擦損失を少く 乙膨張の仕事を速度エネルギーへ有效に転換し，ての 效率を 80 ～85\%にも高めることがでさる。したがっ て，このタービンを酸素製道へ応用することにより從 来寒冷補償の手段之して必要であった冷㶱機など寒冷 発生系統をむったく省略し，しかも空父汪縮操作をす べて低生で行うことが可能となった。これにより，製 品酸素 $(99.6 \%)$ の製造電力原巣位が低減し，長期連 続運転が可能で，また設備の自動化が临単になり，人 件費が軽減でさるようになった。 $40 \mathrm{~kg} / \mathrm{cm}^{2}$ の高圧窒 素を $5 \mathrm{~kg} / \mathrm{cm}^{2}$ まで膨張させて寒冷を発生する膨張夕 一ビンを設借する液化サイクルを組込むことにより数 $1,000 \mathrm{Nm}^{3} / \mathrm{h}$ の大容量液体酸素発生装沙の稼動を可能 とした。

\section{2 酸素の製造と供給}

前項で説明した大容量陵素製造装㴼の一例を図 4 亿 示す。

さて，紙パルプ製造工場における酸素の利用は多種 多様である。酸素蒸解・釜内黑液酸化・中浀度脱リグ ニン・酸素漂白・黑液酸化・排水処理・回収ボイラー 及び生石灰キルンの酸素富化などで消费する酸素の総 量は近い将来パルプ当り $100 \mathrm{~kg}$ に趓するであろうと いわれる。600 t パルプ生産工場では $60 \mathrm{t} /$ 月の消費量 となるから，酸素製造装䍗の十場内設愺も可能である。 世界の実施例は現状では米同バージニヤ州チェサピー ク社が $100 \mathrm{t} /$ 日のプラントを，テキサスガルフコース トにあるオーエンス・イリノイ社オレンジ工場では 59t/日の酸素がビッグ・スリー・オキシジエン社のオ ンサイトプラントから配管供給されている。カナダの エディーフオレストプロダクト社はエスパノラパルプ 


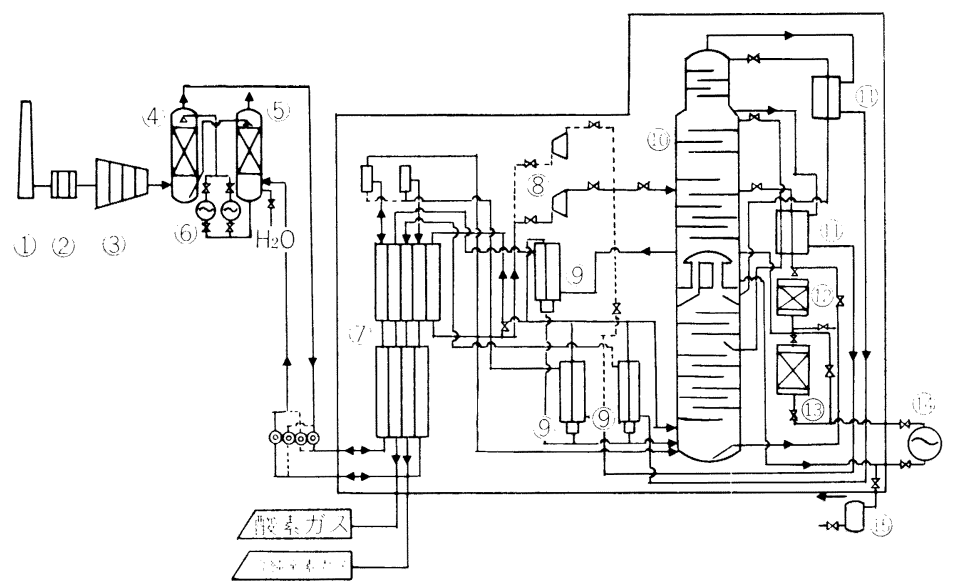
1. 空気吸入塔
2. 空気沪過器
3. 空気圧縮機
4. 水洗冷却塔
5 . 冷 水 塔
6. 水ポンプ
7.リバーシング 熱交換器
8. 膨張タービン
9. 液 化 器
10. 精 留 塔
11. 過 冷 器
12. アセチレン吸着器
13. 循環吸着器
14. 液酸循環ポンプ
15. 液酸放出溜

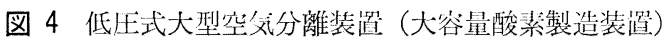

工場に200t/日の陵素プラントを有している。

我が园では，口本酸素が 1976 年に酸素製造 プラン ト(酸素ガス $99.6 \% 3,000 \mathrm{Nm}^{3} / \mathrm{h}$, 液体酸素 $99.8 \% 3,000$ $\mathrm{Nm}^{3} / \mathrm{h}$ ) を北湤道の製紙工場に設置した例がある。

製紙工埸で酸背を使用する埸合，その使用量が月間 30 万 $\mathrm{m}^{3}(12.5 \mathrm{t} /$ 日) 以以であるときは自社工場で酸 素を製造し調迋するよりは液体酸素を酸素メーカーよ り購入した方がコスト的に有利である。酸素の輸送は 小規模ユーザーには高怆ボンベで, 鉄鋼業のような大 規模ユーザーには配管（パイピング）で，それ以外で は極低温の液休陑装の状热で行われている。液体陵素 の大量供給方式はタンクローリーによる輸送，コール ドェバポレーターによる町蔵及びそのガス化の各要素 からなる。(図 5 参照)

液酸 $\left(-183^{\circ} \mathrm{C}\right)$ は主として大父の熱を利用して常

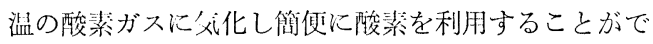
きる。

この方法の特微は

（1）初期設備投資が非掌にわずかである（設備は貸 与としその損用はガス単洒に組み入れる)

(2) 酸素ガスの父化と発生に人件費不要

(3) 酸素ガスの消費量の調節は自由で将来の規模の 桩大が容易である

(4) 酸素をかなり高い任意の压力 (例 : $9 \mathrm{~kg} / \mathrm{cm}^{2}$ ) で利用できる

などで製尴プラント方式では得られない利点である。 ガス状酸点に比べ液酸による酸装ガスの箸洒が高い不 利を相補うものと考えられる。

\section{3. 酸素の利用における安全}

\section{1 酸素取扱いの安全}

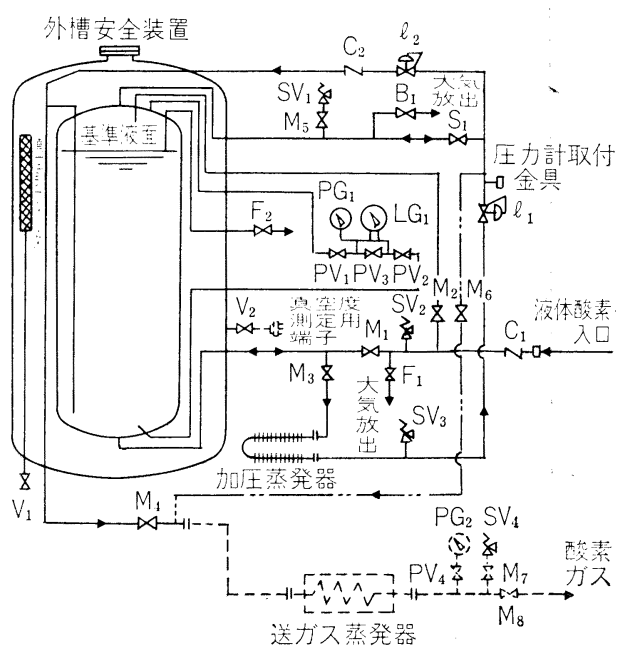

図 5 コールドェバポレーター系統困

架父の代りに酸幸ガスによって酸化処理した場合，

(1) 酸化速度が速くなる

（2）空気中では普通燃焼しない物質でも純酸素ガス 中では燃焼する

（3）燃焼した際発生する燃焼熱は空気中よりも高い

（4）物質の発火温度は空気中ょり低くなる

(5) 酸素中に扣いては酸素と可燃性気体の燃焼範囲 は空気中よりも広く，とくに上限は大幅に広がる 傾向にある

などの物性上の理由により酸素ガスが用いられるよう になってきた。このような理由は酸素を取扱ら面から みれば安全性の点で，その装置は設計，材料，機器の 撰定など特別なエンジニヤリングと運転方式を考虑す る必要がある。

酸素装置に括いて発生する事故の多くは，酸素ガス 


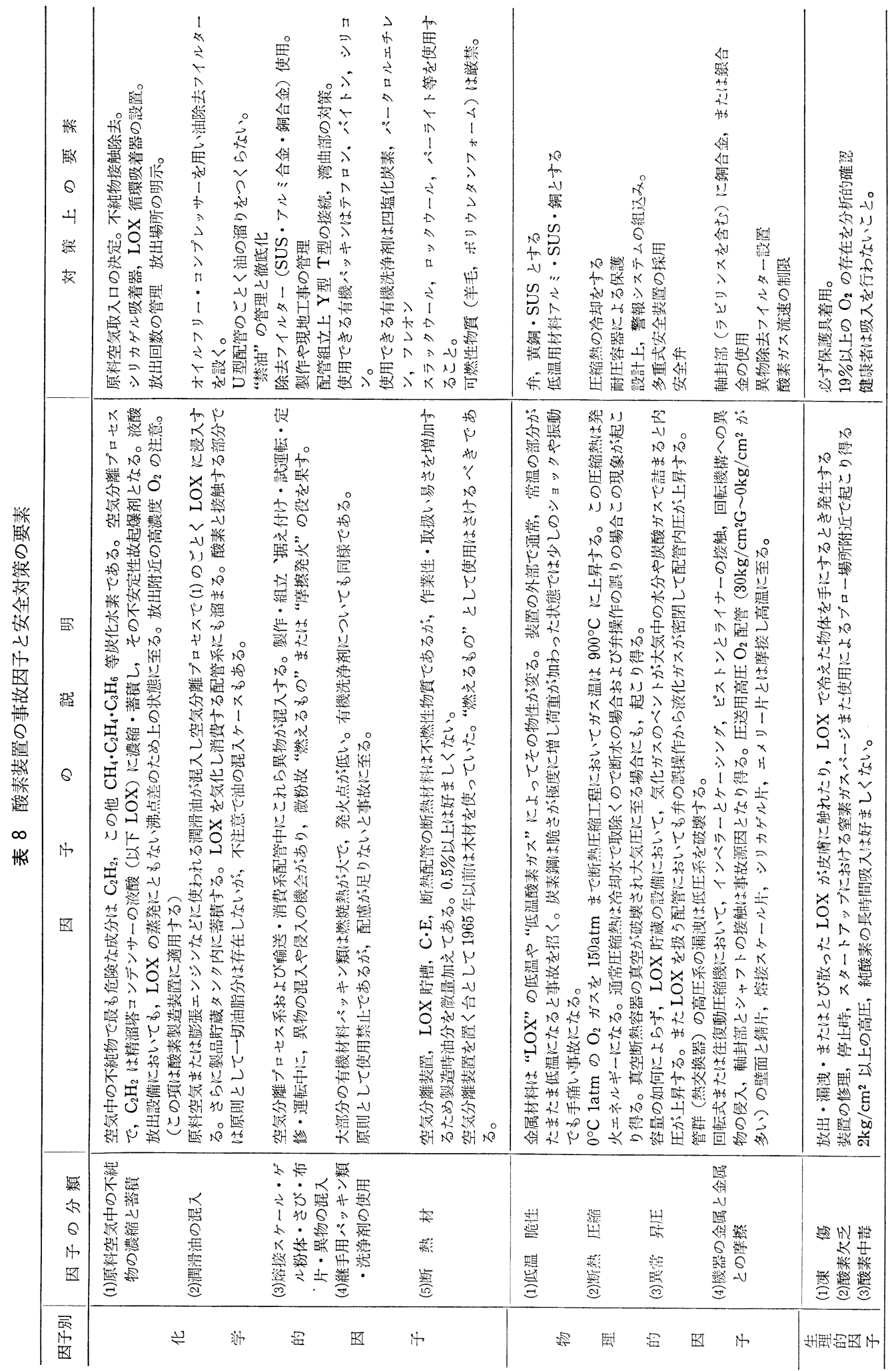


の有する酸化性又は支然性のコントロールに失敗した り息たったりする場合と, 液体酸素の急激な蒸発によ る異常吕压（液封）及びその流体の低温にもとづく装 喼材料の物性の変化に不注:意である場合とにわけられ る。前者の才故は化学的因子（燃えるもの）と酸素存 在下に発火源が介在して然熴爆発災害に結びつく。後 者の事故は物理的团子に起因すると考学られ装置の破 䬉, 酸菜の漏波を引き起こす。䉍単に「酸素装置の事 故因子項日，园于の分類，因子の岲明及び安全詨策の 要素」を表 8 にをとめた ${ }^{5 / 6)}$ 。

酸素ガスを压少 $10 \mathrm{~kg} / \mathrm{cm}^{2} \mathrm{G}$ (温度 $35^{\circ} \mathrm{C}$ に执いて)
以上で取扱ら場合，空気液化を行うとき，液体酸素を 取扱う場合は高圧取締法の適用をらける。酸素の貯蔵 設備であるコールドェバポレーターは“高圧ガス製造 設備”として規定されて扣り，各都道府県知事の許可 が必要である。

\section{2 紙パルプ工程への酸素利用の安全}

酸素・アルカリによるパルプ化，中濃度脱リグニン， パルプの酸素漂白の工程は酸素を加王しつつ，加温下 でリグニンの酸化分解，除去を進める。一方酸素によ る黒液酸化では有機固型物との副反応が進行する。発 熱反応のため系内に熱が蓄積し反応温度が上昇したり，

表 9 木材チップ含有可燃成分特よびK P 関係不純物の物性

\begin{tabular}{|c|c|c|c|c|c|c|c|c|}
\hline 質 & $\begin{array}{l}\text { パイ ン } \\
\text { オイ } \\
\text { Pine oil }\end{array}$ & $\begin{array}{l}\text { メタノール } \\
\mathrm{CH}_{3} \mathrm{OH}\end{array}$ & $\begin{array}{c}\text { メチルエチ } \\
\text { ルケトソ } \\
\mathrm{C}_{2} \mathrm{H}_{5} \\
\mathrm{COCH}_{3}\end{array}$ & $\begin{array}{l}\text { アセトン } \\
\left(\mathrm{CH}_{3}\right)_{2} \mathrm{CO}\end{array}$ & $\begin{array}{l}\text { トール油 } \\
\text { Tall Oil }\end{array}$ & $\begin{array}{l}\text { ピネン・ } \\
\text { ピルフォ } \\
\mathrm{C}_{10} \mathrm{H}_{16}\end{array}$ & $\begin{array}{c}\text { ターペンチ } \\
\text { ソ } \mathrm{C}_{10} \mathrm{H}_{16} \\
\text { Turpen- } \\
\text { tine }\end{array}$ & $\begin{array}{c}\text { メチルメル } \\
\text { カプタン } \\
\mathrm{CH}_{3} \mathrm{SH}\end{array}$ \\
\hline 沸 $\left({ }^{\circ} \mathrm{C}\right)^{\text {点 }}$ & $\stackrel{186.1}{\sim} 226.1$ & 63.89 & 80 & 56.5 & & 155.56 & 148.89 & 5.78 \\
\hline $\begin{array}{l}\text { 燃焼範琞 } \\
\text { 空父仡 } \%\end{array}$ & 不朋 & $7.3-36$ & $1.8-10$ & $2.6-12.8$ & 不 明 & 不 明 & 0.8 一不明 & 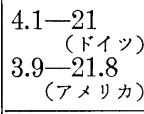 \\
\hline 火災伦険 & 小程度 & $\begin{array}{l}\text { 中积低: } \\
\text { 爆発危众 } \\
\text { 女同様 }\end{array}$ & 左記に同 & 左記に同 & 軽度 & 軽度 & $\begin{array}{l}\text { 中程度, } \\
\text { 爆発険 } \\
\text { 女同様 }\end{array}$ & $\begin{array}{l}\text { 激しい, } \\
\text { 爆発危険 } \\
\text { も同様 }\end{array}$ \\
\hline 引 $\underset{\left({ }^{\circ} \mathrm{C}\right)}{\text { 点 }}$ & $\begin{array}{c}77.78 \\
\text { 蒸留分 } \\
\left(58.89^{\circ} \mathrm{C}\right)\end{array}$ & 11.11 & -6.11 & -17.78 & $\begin{array}{c}\text { ロジン酸に } \\
\text { ついて } \\
112.6\end{array}$ & 32.78 & 35.0 & -17.78 \\
\hline $\begin{array}{c}\text { 発火温度 } \\
\left({ }^{\circ} \mathrm{C}\right)\end{array}$ & & 465 & 515 & 538 & 345 & & 252 & 300 以上 \\
\hline 澌 & $\begin{array}{l}\text { ジメチル } \\
\text { サルハイド } \\
\left(\mathrm{CH}_{3}\right)_{2} \mathrm{~S}\end{array}$ & $\begin{array}{l}\text { ジメチルジ } \\
\text { サルハイド } \\
\left(\mathrm{CH}_{3}\right)_{2} \mathrm{~S}_{2}\end{array}$ & $\begin{array}{l}\text { エチルメル } \\
\text { カプタン } \\
\mathrm{C}_{2} \mathrm{H}_{5} \mathrm{SH}\end{array}$ & $\begin{array}{c}\text { 硫化水素 } \\
\mathrm{H}_{2} \mathrm{~S}\end{array}$ & $\begin{array}{c}\text { 参 考 } \\
\left(\mathrm{CH}_{3}\right)_{2} \mathrm{SO} \\
\text { DMSO }\end{array}$ & $\begin{array}{l}\text { 参 } \text { 考 } \\
\mathrm{CO}\end{array}$ & $\begin{array}{l}\text { 参 考 } \\
\mathrm{CH}_{4}\end{array}$ & \\
\hline 沸 $\left({ }^{\circ} \mathrm{C}\right)^{\text {第 }}$ & $37.5 \sim 38$ & $118 \sim 109.7$ & 35.0 & -57.6 & 188.89 & -191.3 & -161.5 & \\
\hline 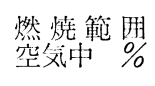 & $2.2-19.7$ & $\begin{array}{c}\text { 下限界 } 2.0 \\
\text { (推定) }\end{array}$ & $2.8-18$ & $4.3-27$ & $2.6-28.5$ & $12.5-74.2$ & $5.3-14.0$ & \\
\hline 火災伦険 & $\begin{array}{l}\text { 湤しい, } \\
\text { 䈋発伦㭘 } \\
\text { 女间様 }\end{array}$ & 中程度 & $\begin{array}{l}\text { メチルメ } \\
\text { ルカプタ } \\
\text { ソに同じ }\end{array}$ & $\begin{array}{l}\text { 熱または } \\
\text { 炎にざ } \\
5 さ れ る \\
\text { らさ㑑被 } \\
\text { 害は中程 } \\
\text { 度 }\end{array}$ & 中程 度 & $\begin{array}{l}\text { 熱または火 } \\
\text { 炎にさらさ } \\
\text { れる亡爆発 } \\
\text { 危険。炎资 } \\
\text { にさらされ } \\
\text { ると危険 }\end{array}$ & $\begin{array}{l}\text { 熱または } \\
\text { 火炎にさ } \\
\text { らされる } \\
\text { 之危険 }\end{array}$ & \\
\hline 引 $\underset{\left({ }^{\circ} \mathrm{C}\right)}{\text { 点 }}$ & $-27>$ & 不 明 & 300 & ガ ス & 67 & ガ & ガ & \\
\hline $\begin{array}{c}\text { 発火温度 } \\
\left({ }^{\circ} \mathrm{C}\right)\end{array}$ & 206 & 200 以上 & 299 & $\begin{array}{l}292 \text { in Air } \\
220 \text { in } \mathrm{O}_{2}\end{array}$ & 445 & 609 & 538 & \\
\hline
\end{tabular}


一酸化炭素やメタンガスが副成する。黑液中に含まれ るメルカプタン類は可然性ガスなので，酸素との混合 物は着火エネルギが存在すれば燃焼する。表 97 ) のよ らに木材チップはアルコールやケトン，ターペンチン など揮発性有機物質を含んで括り引火点が低く燃烍下 限界も小さい。従ってこの点注目するとさ酸素を使 用する反応装置においては，次のような安全上の配急 が必要である ${ }^{8) ~ 14) 。 ~}$

(1) 酸素脱リグニン反応時，一酸化炭素や揮発性炭 化水素が副生するので, 反応系より除去し気相安 全の確認を行う

（2）装置の安全を確保するには，定期的にブローす ることが望ましい

(3) $20 \%$ ３0\%のような高濃度パルプに比較し，中 濃度パルプで脱リグニンを行らと一酸化炭素の発 生は $30 \%$ も少くなる。1 モルの一酸化炭素に対 乙炭化水素は 0.3 モルの比で発生する

(4) 酸素脱リグニン反応装置の一つの問題は, 反応 気相部分飞蓄積する炭化水素が高温の高濃度酸素 ガスと爆発混合組成を形成するので，安全上から は気相空間を極力減らすことが望ましい

（5）一酸化炭素ガス濃度はドライベースで $3 \%$ を越 总ないこと，炭化水素は $1 \%$ を越光ないこと

(6) パルプ濃度と発火性の関係は（電気加熱つィラ メントの点火テスト), パルプ濃度が $30 \%$ 以下で は着火しにくいが $40 \%$ をこすと燃燒が始まった。 燃焼は表面のみでシャワーで容易汇消学る。買常 な圧力上昇や温度上年飞対しては破裂板や安全弁 の設置が有効である

（7）可燃性有機物は消泡剂として使用しないこと

（8）酸素蒸解脱リグニン反応装置に抢ける操業の安 全性確保のための条件

(1) ラプチャーディスクの設唯

(2) 安全升の設睢
(3) $\mathrm{CO}$ ガスの連続測定

(4) 温度, 压力の買常上垶峙のインターロック

(5)润滑油，消泡剂は燃㹸しにくいものを選定

（9）パルプ蕽度をたとえ $30 \%$ 以下に制御しても，

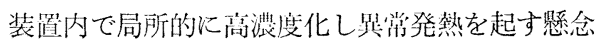
がある。 $\mathrm{O}_{2}$ 吹き込及近傍义は高湿度の恐れが予 想される部位に水・アルカリ水, スチームを嘪霧 し，安全化を図ることも浮党られる。

\section{4. 酸素の用途}

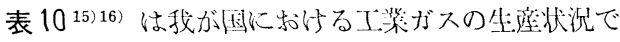
酸素法全体の約 $57 \%$ を占約 840 万 $\mathrm{t}$ の生産量であ る。

その用途を 1981 年の統計でみると70\%は鉄鋼業， $16.5 \%$ が化学・パルプ，7\%が機玳工策そして残りが

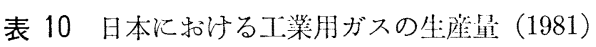

\begin{tabular}{|c|c|c|}
\hline ガスの種類 & 生 源 型 & 百分率 \\
\hline 素 & 8,368 千 $\mathrm{t}$ & 57.16 \\
\hline 筑 装 & 5,676 & 38.77 \\
\hline 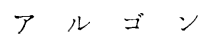 & 148 & 1.01 \\
\hline 水奖 & 6 & 0.04 \\
\hline 溶解アセチレン & 39 & 0.27 \\
\hline 炭酸 ガ ス & 403 & 2.75 \\
\hline 合 & 14,640 & 100.00 \\
\hline
\end{tabular}

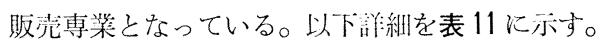

すなわち（1）その酸化反心性を利用し化成品を製造

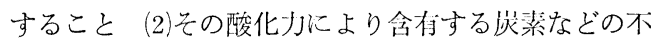
純物を除き金属精鋉を行うこと（3)水䋕やアセチレン を燃料とし酸素で酸化燃炟し発生する问熱で金属を加 エすること (4)生物酸化反心性を利用し生ずるエネル ギーで生物の活動を促進することの四つの用途に大別 できる。

表 11 酸素の用途一覧

\begin{tabular}{|c|c|c|c|}
\hline 産 & 業 & 用 & アプリケーション技術要求 \\
\hline \multirow{3}{*}{ 金 } & \multirow{3}{*}{ 属 } & 金属の加工 & 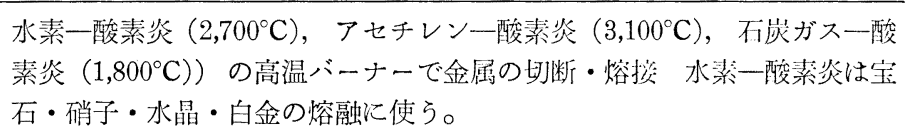 \\
\hline & & 製 銑・製 鋼 & $\begin{array}{l}\text { 前者は酸素富化 (23\%) 空気を使う。後者は純酸奖で脱岸・脱燐・脱硫な } \\
\text { ぞ不純物の除去を行う。 }\end{array}$ \\
\hline & & $\begin{array}{l}\text { 銅 の 精 鍊 } \\
\text { 韭鉛の精鍊 }\end{array}$ & 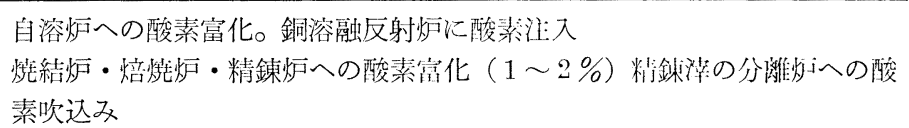 \\
\hline
\end{tabular}




\begin{tabular}{|c|c|c|}
\hline & $\begin{array}{l}\text { 鉛 の 精 錬 } \\
\text { 鋳物の生 産 } \\
\text { アルミニウム・銅合金溶 } \\
\text { 解 }\end{array}$ & $\begin{array}{l}\text { 溶解炉への酸素富化 } \\
\text { 酸素富化 } 1 \text { 〜 } \% \text { でキュポラは溶解速度上昇 } \\
\text { 酸素一燃料バーナーの中性炎か, 還元炎溶解する }\end{array}$ \\
\hline \multirow{5}{*}{ 化 学 } & 石 油 化 学 & $\begin{array}{l}\text { エチレンオキシドを銀触媒を用い酸素とエチレンから合成炭化水素と塩酸 } \\
\text { と酸素を反応させ塩化物合成（オキシクロリネーションと言い塩化ビニル } \\
\text { 製造法）エチレン・酸素の一段反応によりアセトアルデヒド合成（ヘキス } \\
\text { トウッカー法） } \\
\text { 一段気相接触法によるプロピレン・アンモニア・酸素からアクリロニトリ } \\
\text { ルの製造（モンモ酸化） } \\
\text { 炭化水素と水蒸気と酸素の反応による合成ガスの製造（水素と一酸化炭素 } \\
\text { の混合ガス。原料ナフサ LPG） }\end{array}$ \\
\hline & 石 炭 化 学 & $\begin{array}{l}\text { 石炭粉末・酸素・水蒸気から石炭ガス }\left(\mathrm{H}_{2} 59, \mathrm{CO} 26, \mathrm{CH}_{4} 12, \mathrm{CO}_{2} 1 \% \text {, }\right. \\
\left.\mathrm{H}_{2} \mathrm{~S}\right) \text {, さらに石炭ガスから液体燃料への合成 }\left(\mathrm{nH}_{2}+2 \mathrm{nCO} \rightarrow\left(\mathrm{CH}_{2}\right) \mathrm{n}+\right. \\
\left.\mathrm{nCO}_{2} \text {, などフイッシャートロピシュの反応 }\right) \\
\text { 石炭を乾留しガスと油を得, 残留チャーを } 900^{\circ} \mathrm{C} \text { 加熱水蒸気と酸素と反 } \\
\text { 応し } \mathrm{CO} \text { と } \mathrm{H}_{2} \text { が生成, さらにメタネーションにより } \mathrm{CH}_{4} \text { とする。（米 } \\
\left.\text { 国の開発した HYGAS 法, 石炭 } 1 \mathrm{t} \mathrm{O}_{2} 140 \mathrm{~m}^{3}\right)\end{array}$ \\
\hline & 紙・パ ルプ & $\begin{array}{l}\text { 酸素アルカリ蒸解によるパルプ製造, 酸素漂白, 釜内黒液・稀黒液・濃黒 } \\
\text { 液の酸素酸化 } \\
\text { ライムキルンやアルカリ回収炉への酸素富化 }\end{array}$ \\
\hline & セメント & $\begin{array}{l}\text { ロータリーキルンヘの } \mathrm{OF} \text { バーナーの利用 } \\
\text { アルミナ系セメント溶解炉への空気, 酸素バーナー併用 }\end{array}$ \\
\hline & ガ ラ ス & 板ガラス用の溶解炉への空気, 酸素バーナー併用 \\
\hline 子 & 半 導 体 製 造 & シリコン酸化膜の生成 \\
\hline 海洋開発 & $\begin{array}{l}\text { 海底岩盤掘削 } \\
\text { 潜水用呼吸ガス }\end{array}$ & $\begin{array}{l}\text { ケロシン等を燃料とする超音速ジェットバーナー } \\
\text { 深海潜水にヘリウム一酸素混合ガスを使用し窒素酔いの防止 }\end{array}$ \\
\hline \multirow{4}{*}{ 生 物 物 } & 医 療用 酸 素 & 酸素呼吸器・酸㨞テント・高気圧酸素治療室など \\
\hline & 吸 入 用 & アクアラング，航空機吸入用 \\
\hline & 養＼cjkstart魚 & $\begin{array}{l}\text { 純酸素または酸素富化空気を使用し魚の生活体謝を活発にする。 } \\
\text { 活魚の遠隔地への輸送 }\end{array}$ \\
\hline & 躌 酵 工 業 & $\begin{array}{l}\text { 石油系人工蛋白の製造への利用 微生物醗酵タンクの酸素富化 水素炭酸 } \\
\text { ガス酸素混合ガスと徽生物利用による多糖類造 }\end{array}$ \\
\hline \multirow{5}{*}{$\begin{array}{l}\text { 廃裹物特 } \\
\text { Lひ排 } \\
\text { 処理 }\end{array}$} & $\begin{array}{l}\text { 酸素活性污泥法による排 } \\
\text { 水里 }\end{array}$ & 懪気槽の能力は空気槽の約 3 倍となる。 \\
\hline & 湖沼・河川の浄化 & $\begin{array}{l}\text { 富栄養化が原因の污濁河川や湖沼に酸素曝気を行い，徽生物を介して生化 } \\
\text { 学的浄化 }\end{array}$ \\
\hline & 乙 尿 処 理 & メルカプタン, アミン系の悪臭を酸素の一部をオゾンに転化して使用 \\
\hline & 都市ごみの処理 & $\begin{array}{l}\text { 空気〜酸素の二段方式，純酸素の一段方式により，1,600〜 } 1,700^{\circ} \mathrm{C} \text { まで昇 } \\
\text { 温し， あらゆる固型物を焼却・溶融・熱分解する }\end{array}$ \\
\hline & $\begin{array}{l}\text { PCBの焼却処理 (ポリ塩 } \\
\text { 化ビフェニール) }\end{array}$ & 純酸素により $1,400^{\circ} \mathrm{C}$ で熱酸化分解処理 \\
\hline 宇宙開発 & ロケット打上用 & $\begin{array}{l}\text { 固体燃料かケロシン一液体酸素が現在のロケット推進剤となっている。今 } \\
\text { 後液体水素一液体酸素が大きな推力を活用するためのシステムとして開発 } \\
\text { が期待でさる。 }\end{array}$ \\
\hline
\end{tabular}




\section{おわりに}

紙パルプ製造工程への酸菜利用は1980 年代に入り 中濃度 $\mathrm{O} / \mathrm{E}$ 酸素漂白を中心急速な展開を見せてい る。これは酸素が他の漂白薬品に比べて安価であり脱 リグニンの性能も同等以上であるためと思われる。し か子 COD, BOD, カラーのカットなど環境浄化能力 が高く評価されてきたからであろら。酸薪の利用は今 後, 一段と広がると思われるので本稿では, 酸素を無 事故で効率よく利用するための「酸点の基礎と伈用」 を歴火・基礎・製造・安全・用途にわけて解説した。 十分に説明できない而については機会があれば補起し たいと考える。

な扣，酸素の製造法として，古典的な水の電父分解 法があるが，今日実施例は極めて少い。

一方，新規なものに，吸着剤を利用する PSA 方式， 及び合成樹脂膜を応用する膜分離法がある。空気から 酸素を濃縮し製造できるので，今日，開発工業化へと 展開しつつある。これらについては, 別な機会に解説 し展望してみたい。

\section{参考文献}

1) 小林・吉田：姿全工学 11 (2) 106 (1972)

2) CGA : Handbook of compressed gases Reinhold (1981)

3) 井口・林汪吕：陵素の化学 共立出版 (1974)

4）館・橋井ほか：わが国に扣ける酸菜製鋼法の歴尘 日本鉄鋼協会 (1982)

5) 橋井・西阙: 高比ガス 8 (6) 370 (1971)

6) 橋井・洲合：安全 20 (5) 45 (1969)

7) NFPA : Fire hazard properties of liquids and volatile solids, 13 (1976)

8) V. L. Magnotta : Tappi 63 (11) 80 (1980)

9) P.P.I : Pulp Paper Industry Jan. 63 (1982)

10）国中：紙パルプ技術タイムス（7）47（1983）

11）福田：紙パルプ技術協会, 年次大会（1983）

12) 外山：安全工学 13 (1) 24 (1974)

13）橋井・太州：特許 1239955号 Nov. 13 (1984)

14）鈴木：紙パルプ技術協会 第4[回環境シンホホジリ 么 (1976)

15) 三浦：化学丁策 1979年 1 月号691

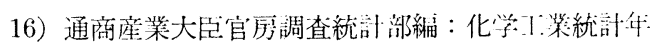
報 1981年 